\title{
sciendo PROBABILISTIC-DETERMINISTIC METHOD OF RESCALING SHIP MANOEUVRING SIMULATION DATA DEFINING PARAMETERS OF FAIRWAY BENDS
}

DOI 10.2478/ntpe-2018-0016

\author{
Prof. Stanisław Gucma \\ Dr. Rafał Gralak \\ Maritime University of Szczecin, Poland
}

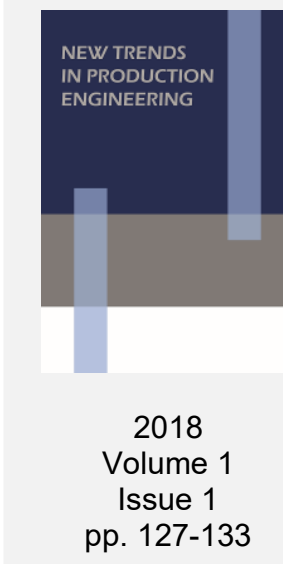

\begin{abstract}
The article presents a method of scaling up existing simulation tests results from ships with parameters $L_{1}, B_{1}$ (length and breadth) determining a safe waterway bend width $\left(d_{1}\right)$ to specify a width $\left(d_{2}\right)$ safe for ships with other dimensions $L_{2}, B_{2}$. This method enables accurate determination of the safe fairway width $(d)$ in case it has been planned to increase maximum length and width of vessels without carrying out relatively expensive simulation tests. The method was used in designing the parameters of the modernized Swinoujscie-Szczecin fairway.
\end{abstract}

Keywords: fairways, maneuvering of vessels, method of simulating vessel movement

\section{INTRODUCTION}

It often occurs in practice that previously established conditions for safe ship operation in a specific waterway (fairway) have to be changed, or more precisely, length $(L)$ and breadth $(B)$ of 'maximum ships' are to be increased. The change of these parameters makes it necessary to increase the width of the navigable area of a waterway.

If maximum lengths and breadths of ships operated on a given waterway are expected to be increased, waterway widths (d) safe for these ships can be determined using empirical or simulation methods.

Empirical methods are approximate (Gucma, 2001, Gucma, 2015). Some methods prove to be fairly good when it comes to calculating the parameters of straight waterways, but in case of bends the results vary, which additionally depends on two factors: bend parameters (angle and radius of turn) and types of ships (Japan Institute of Navigation, 2003, PIANC, 1997, PIANC, 2014, Puertos Del Estado, 2007, USACE, 2008).

Simulation methods for determining waterway bend parameters are detailed methods establishing bend parameters with practically sufficient accuracy. Simulation tests of fairway bends are based on a specially developed methodology of tests on simulators with 3D display. Tests are run by navigators (captains, marine pilots) with appropriate qualifications. Simulation methods are, however, much more expensive than empirical methods (Gucma et al., 2008, Gucma et al., 2015).

The method presented in the article allows to rescale existing results of simulation tests of "maximum ship" with parameters $L_{1}, B_{1}$ determining the safe width of the fairway $\left(d_{1}\right)$ to a scaled up fairway width $\left(d_{2}\right)$, safe for ships having other dimensions $L_{2}, B_{2}$.

Simulation tests of ship manoeuvres intended to determine parameters of waterways (approach channel, port entrance, inner fairway) are performed for ships whose parameters determine the conditions of their safe operation. Conditions of safe operation of ships in the waterway (fairway) are described by a vector of the safe operation of a maximum ship proceeding along that fairway:

where:

$$
W=\left[t_{\text {ype }}, L_{C}, B, T, H_{s t}, V_{i}, H_{i}\right]
$$

- $t_{\text {ype }}$ type of 'maximum ship';

- $L_{C}$ length overall of 'maximum ship'; 
- $B$ breadth of 'maximum ship';

- $T$ daft of 'maximum ship';

- $H_{s t}$ irdraft of 'maximum ship';

- $V$ alowable speed' of the 'maximum ship' in i-th fairway section;

- $H$ a set of hydrometeorological conditions acceptable for a 'maximum ship' on the fairway.

The waterway system such as a fairway or port entrance is defined by parameters of its elements (subsystems). Two elements of this system are a function of conditions for safe operation of ships maneuvering within those waterways (Gucma et al., 2013, Gucma et al., 2015).

$$
\left[\begin{array}{l}
A \\
N
\end{array}\right]=F(W)
$$

where:

- $W$ conditions of safe operation of ships on the fairway;

- $A$ area (fairway ) subsystem;

- $N$ navigation subsystem of the fairway.

Where the navigation subsystem is not changed in the process of scaling up, we can write:

$$
A=F(W)
$$

The area (fairway) subsystem is described by a set of parameters, in which the only parameter scaled up is safe fairway width $(d)$, so we can write:

$$
d=f(W)
$$

where:

$N=$ const

$H=$ const

\section{THE METHOD OF RESCALING SIMULATION TEST DATA BASED ON THE PROBABILISTIC-DETERMINISTIC MTEC METHOD}

The probabilistic-deterministic method developed at the Marine Traffic Engineering Centre (MTEC) was used to calculate fairway widths at the bottom defined by the simulation method and determine other parameters of ships expected to be operated therein.

The MTEC method (Gucma et al., 2015, Gucma and Zalewski, 2005), created at the Maritime University of Szczecin, allows us to determine parameters of a approach waterway system (strait fairway sections and bends) and is characterized by a relatively high reliability. The method defines the maneuvering component of safe maneuvering area width (swept path) $\left(d_{m}\right)$ eterministically, while the navigational component of the maneuvering area width is of probabilistic nature and is estimated at a certain level of confidence $d_{n(1-\alpha)}$.

Navigation will be safe along a straight one-way section of the fairway provided that this relation is fulfilled: $d_{(1-\alpha)}$

where:

$$
D_{j} \geq d_{(1-\alpha)}+d_{r}^{p}+d_{r}^{l}=d_{m}+2 d_{n(1-\alpha)}+d_{r}^{p}+d_{r}^{l}[\mathrm{~m}]
$$

- $D_{j}$ width at the bottom at $j$-th point of the fairway centre line with safe depth [m]:

- $d_{(1-\alpha)}$ width of the safe maneuvering area at the specific level of confidence [m];

- $d_{m}$ the maneuvering (deterministic) component of the safe maneuvering area width [m];

- $d_{n(1-\alpha)}$ the navigational (deterministic) component of the safe maneuvering area width [m];

- $d_{r}^{p}$ margin of maneuvering area width on the right-hand side [m];

- $d_{r}^{l}$ margin of maneuvering area width on the left-hand side [m].

It should be noted that to determine parameters of the approach waterway system we choose such fairway sections in which at each $j$-th point of the fairway centre line this condition is satisfied: $d_{n(1-\alpha)}=d_{j(1-\alpha)}=d_{j+1(1-\alpha)}$.

It is assumed in the above relationship for a one-way section of the fairway that navigation components of the safe maneuvering area on the left and right hand sides are equal:

$$
d_{n(1-\alpha)}=d_{n(1-\alpha)}^{p}=d_{n(1-\alpha)}^{l}[\mathrm{~m}]
$$

where: 
- $d_{n(1-\alpha)}^{p}, d_{n(1-\alpha)}^{l}$ navigation components (right and left) of safe maneuvering area width at the confidence level [m].

If the margins of maneuvering area width on the right and left side are also equal (for similar slopes of the channel):

$$
d_{r}^{p}=d_{r}^{l}=d_{r}[\mathrm{~m}]
$$

the condition of navigation safety can be written as follows:

$$
D \geq d_{m}+2 d_{n(1-\alpha)}+d_{r}[\mathrm{~m}]
$$

where:

- $d_{r}$ margin of maneuvering area width [m].

In a one-way traffic bend the width of a safe maneuvering area at confidence level (1- $\alpha)$ is determined by this relationship:

$$
d_{z(1-\alpha)}=d_{m z}+2 d_{n(1-\alpha)}[\mathrm{m}]
$$

where the maneuvering component of the maneuvering area width is, respectively:

$$
d_{m z}=d_{m}+\Delta d[\mathrm{~m}]
$$

where:

- $d_{z(1-\alpha)}$ safe maneuvering area width for a bend at the confidence level $(1-\alpha)$;

- $d_{m z}$ maneuvering component of the safe manoeuvring area within a bend;

- $d_{m}$ maneuvering component of safe manoeuvring area width in a straight section;

- $\Delta d$ widening of the vessel's swept path in a bend.

The widening of a ship's swept path in a bend depends, inter alia, on the angle and radius of the turn, and the speed and length of the ship and, according to Taylor's formula (PIANC, 1997), is equal to:

$$
\Delta d=\frac{3,4551 \cdot \Delta \psi \cdot V^{2} \cdot L_{C}^{2}}{r \cdot k_{Z} \cdot S}[\mathrm{~m}]
$$

where:

- $\Delta \Psi$ angle of turn (course alteration) in the bend $\left[^{\circ}\right]$;

- $V$ ship's speed $[\mathrm{m} / \mathrm{s}]$;

- $r$ the radius of bend arc [m];

- $s$ minimum required visibility from the ship's bridge $>2446 \mathrm{~m}$;

- $k_{z}$ ship maneuverability ratio (1 - poor, 2 - good, 3 - very good).

To determine the maneuvering component $\mathrm{dm}$ of maneuvering area width in a rectilinear fairway section, a modified deterministic PIANC method is used. The maneuvering component for ships maneuvering without assistance is calculated by this relationship:

$$
d_{m}=d_{m p}+\sum_{i=1}^{7} d_{i}[\mathrm{~m}]
$$

where:

- $d_{m p}$ basic maneuvering width of the swept path [m];

- $d_{i}$ additional allowances of swept path width.

The basic maneuvering width of the swept path and additional allowances are determined as a function of the ship's breadth, i.e. after addition (Gucma and Zalewski, 2005, PIANC, 1997):

$$
d_{m}=c \cdot B
$$

where:

- $c$ sum of the coefficients of the basic maneuvering width and all additional allowances.

The MTEC method assumes that the navigational component is represented by a sum of standard deviations of maximum distances of points on the conventional waterplane to the right and left of the fairway centre line.

For a fairway bend, the standard deviation is approximated by a directional error of bow position perpendicular to the fairway centre line tangential at a given point, determined at a certain level of confidence (Gucma et al., 2015):

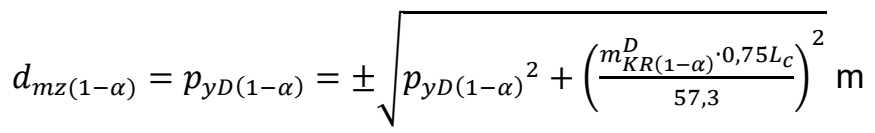

where: 
$p_{y D(1-\alpha)}$ directional error of bow (stern) position at a confidence level (1- $\left.\alpha\right), \mathrm{m}$;

$m_{K R(1-\alpha)}^{D}$ error of ship course determination and maintenance in a fairway bend confidence level (1- $\alpha)$, deg.

The fairway width margin $\mathrm{dr}$ allowing for the bank-channel effect, defined as a function of ship's breadth:

where:

$$
d_{r}=k \cdot B
$$

$k$ depends on ship's speed (V) and the type of fairway banks (PIANC, 1997).

The following assumptions were made in working out the method of scaling up simulation test results:

1. The scaling up concerns only changes in ship parameters:

- length overall $L_{C}$;

- breadth $B$.

2. The parameters of fairway bends, or turns, and parameters of aids to navigation remain unchanged.

3. The other conditions for safe operation of the ship remain unchanged.

With the above assumptions, in order to scale up the widths of safe maneuvering areas defined by the simulation method $d_{(1-\alpha) 1}$ for a ship with parameters $L_{1}$ and $B_{1}$ to specify safe maneuvering areas $d_{(1-\alpha) 2}$ for ships with parameters $L_{2}$ and $B_{2}$, it has been assumed that navigational components of the safe maneuvering area remain unchanged for both ships:

$$
d_{n(1-\alpha) 1}=d_{n(1-\alpha) 2}
$$

Such assumptions can be accepted due to small differences in the navigational component of the safe maneuvering area width, when changing the ship's length within $25 \%\left(L_{c} \approx 200 \mathrm{~m}\right)$, these differences do not exceed one metre for terrestrial aids to navigation systems.

Given the above assumptions, it was established that the scaling up of safe maneuvering area width for ships refers to the maneuvering component of ship's swept path width $\left(d_{m}\right)$ and the margin of maneuvering area width $\left(d_{r}\right)$.

The maneuvering component of the safe maneuvering area width in fairway bends is a function of ship's manoeuvrability $\left(S_{t}\right)$, breadth $(B)$ and the extension of the swept path in bends $(\Delta d)$ :

$$
d_{m z}=f\left(S_{t}, B, \Delta d\right)
$$

The widening of swept path in a bend depends, inter alia, on the angle and radius of the turn, ship's speed and length. For unchanged ship's parameters of ship's turn and speed we can assume that $\Delta d$ will be a function of ship's length, i.e.:

$$
d_{m z}=f\left(S_{t}, L_{c}, B\right)
$$

The probabilistic-deterministic MTEC method was used for scaling up the results of simulation test results, i.e. widths of safe maneuvering areas for ships of different lengths and breadths. The method enabled a relative change of the maneuvering component width and a margin of maneuvering area width for ships under consideration with parameters, respectively, $L_{C_{1}}, B_{1}$ and $L_{C 2}, B_{2}$. This relative change is defined by a scaling factor $K$. The scaling factor is found differently for strait fairway sections and bends. In fairway bends the scaling factor is, respectively:

therefore:

$$
K=\frac{d_{m z 2}+d_{r 2}}{d_{m z 1}+d_{r 1}}
$$

$$
K_{z}=\frac{(c+k) B_{2}+a L_{c 2}^{2}}{(c+k) B_{1}+a L_{c 1}^{2}}
$$

The factor (a) is derived from Taylor's formula and equals:

$$
a=\frac{3,4551 \cdot \Delta \psi \cdot V^{2}}{r \cdot k_{s} \cdot s} \mathrm{~m}
$$

The procedure for scaling up simulation tests results determining the safe fairway widths consists of these steps, taken to determine:

1. the scaling factor $K$ for simulation test results; 
2. the navigational component of safe fairway width in bends for assumptions made in simulations in reference to the navigation system parameters, the same for the two ship sizes:

$$
d_{n(1-\alpha)}= \pm \sqrt{p_{y(1-\alpha)}{ }^{2}+\left(\frac{m_{K R(1-\alpha)}^{D} \cdot 0,75 L_{c}}{57,3}\right)^{2}}
$$

the maneuvering component of safe fairway width in bends and its margin determined by simulation tests for a ship with parameters $L_{C 1}, B_{1}$ :

$$
d_{m 1}+d_{r 1}=d_{(1-\alpha) 1}-d_{n(1-\alpha)}
$$

3. safe width of the fairway in bends, scaled up to the new parameters of ship $L_{C 2}$ and $B_{2}$ :

$$
d_{(1-\alpha) 2}=\left(d_{m 1}+d_{r 1}\right) K+d_{n(1-\alpha)}
$$

where:

$d_{(1-\alpha) 2}$ safe fairway width in bends, determined by the simulation method for a ship with parameters $L_{c 1}, B_{1}$.

\section{THE VERIFICATION OF THE METHOD BASED ON SIMULATION TESTS}

The method was verified for the actual bend, Zakret Mankow, part of Swinoujscie-Szczecin fairway (turn angle $\Delta \psi=26^{\circ}$, arc radius $r=2200 \mathrm{~m}$ ). Simulation tests were carried out on the Polaris FMBS from Konsberg, installed at the Marine Traffic Engineering Centre, Maritime University of Szczecin. Models of tested bulk carriers were developed using the Hydrodynamic Modelling Tool (Akademia Morska w Szczecinie, 2014). Two models of bulk carriers had these parameters:

1. $L_{C 1}=195 \mathrm{~m} ; B_{1}=29.0 \mathrm{~m} ; T_{1}=11.0 \mathrm{~m}$

2. $L_{C 2}=265 \mathrm{~m} ; B_{2}=32.3 \mathrm{~m}, T_{2}=11.0 \mathrm{~m}$.

The simulation experiment consisted in passing through the Mankow bend (entrance to Szczecin) by each of the bulkers, with wind speed $10 \mathrm{~m} / \mathrm{s}$ from NW and SW - two separate series. The ships were steered by several sea pilots and captains with maneuvering experience. Each series consisted of 12 passages. Statistical analysis used in marine traffic engineering was employed to process the simulation test data and determine safe maneuvering areas at the confidence levels $0.5,0.95$ and maximum, for each of the tested bulk carriers and NW and SW winds.

The verification of the developed method involved a comparison of the width of two safe maneuvering areas recorded for Mankow bend passages:

1. The safe maneuvering area of the bulker $L_{C 2}=265 \mathrm{~m}$ determined by the deterministicprobabilistic method of scaling up the simulation test results of the bulk carrier with $L_{C 1}=$ 195 m (Akademia Morska w Szczecinie, 2014).

2. The safe maneuvering area of the bulk carrier $L_{C 2}=265 \mathrm{~m}$ determined by the simulation method (Fig. 1).

The differences between these widths in the central part of the bend are $1.75 \%$, in the end part $(2 / 3)-3.7 \%$.

The difference between the ships taken for verification was, respectively:

- length overall: approximately $35 \%$;

- breadth: approximately $11.5 \%$. 


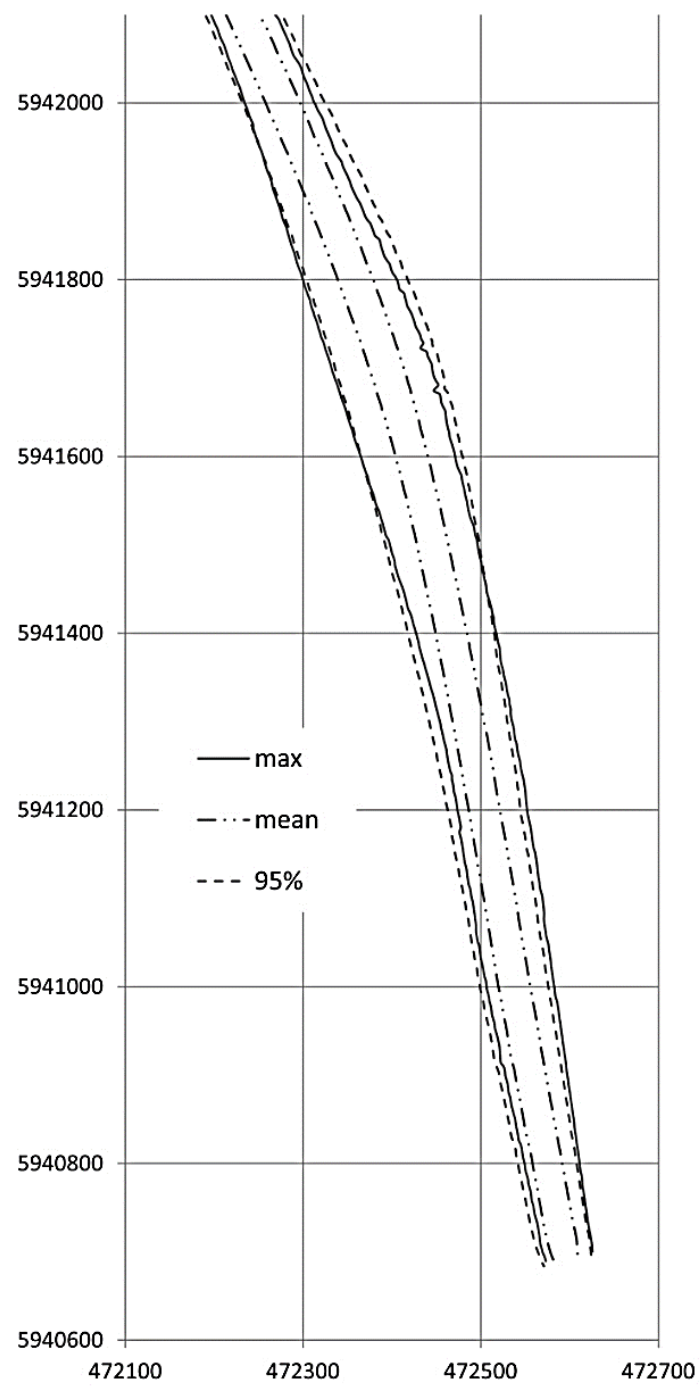

Fig. 1. Safe manoeuvring areas of the bulk carrier Lc $=265 \mathrm{~m}$ in the Mankow bend. Wind $10 \mathrm{~m} / \mathrm{s} \mathrm{NW}$ and SW (results of simulation tests)

\section{CONCLUSION}

The article presents a probabilistic-deterministic method of scaling up the existing simulation test results of the 'maximum ship' parameters based on parameters $L_{C 1}, B_{1}$ defining the safe bend width $\left(d_{1}\right)$ to the scaled up width of the bend $\left(d_{2}\right)$, safe for a ship with parameters $L_{C 2}, B_{2}$. The accuracy of this method can be estimated at a level of $5 \%$ of the safe fairway width when the changes in ship's length overall and breadth range up to $30 \%$.

The method was used in the optimization of the parameters of the upgraded ŚwinoujścieSzczecin fairway, its section 5.3 to $17.4 \mathrm{~km}$ (Akademia Morska w Szczecinie, 2017).

\section{REFERENCES}

Akademia Morska w Szczecinie. (2014). Analiza nawigacyjna modernizacji toru wodnego Świnoujście-Szczecin (pogłębienie do 12,5m). Szczecin: Akademia Morska w Szczecinie.

Akademia Morska w Szczecinie. (2017). Optymalizacja szerokości toru wodnego SzczecinŚwinoujście pogłębionego do $12,5 \mathrm{~m}$ na odcinku od $\mathrm{km} \mathrm{5,28}$ do km 17,4. Szczecin: Akademia Morska w Szczecinie.

Gucma, S. (2001). Inżynieria ruchu morskiego. Gdańsk: Wydawnictwo "Okrętownictwo i Żegluga".

Gucma, S., Gucma, L. and Zalewski, P. (2008). Symulacyjne metody badań w inżynierii ruchu morskiego. Szczecin: Wydawnictwo Naukowe Akademii Morskiej w Szczecinie.

Gucma, S., Ślączka, W. and Zalewski, P. (2013). Parametry torów wodnych i systemów nawigacyjnych wyznaczane przy wykorzystaniu bezpieczeństwa nawigacji. Szczecin: Wydawnictwo Naukowe Akademii Morskiej w Szczecinie. 
Gucma, S., Zalewski, P. (2012). Deterministic-probabilistic method of waterway design parameters determination. Annual of Navigation, 19/2012(2), pp. 19-30.

Gucma, S. et al. (2015): Morskie Drogi Wodne. Projektowanie i eksploatacja w ujęciu inżynierii ruchu. Gdańsk: Fundacja Promocji Przemysłu Okrętowego i Gospodarki Morskiej.

Japan Institute of Navigation. (2003). Design Standard for Fairway in Next Generation. Tokyo: National Institute for Land an Infrastructure Management, Port and Harbor Department.

PIANC. (1997). Approach Channels. A. Guide for Designs. PTC II-30, Final report of the joint Working Group PIANC and IAPH in cooperation with IMPA and IALA. Supplement to Bulletin, 95. Bruxelles: PIANC

PIANC. (2014). Setting the Course, Harbour Approach Channels - Design Guidelines, Report n $121-2014$, Final report of the joint Working Group PIANC and IAPH in cooperation with IMPA and IALA. Bruxelles: PIANC

Puertos Del Estado. (2007). ROM 3.1-99, Design of the Maritime Configuration of Ports, Approach Channels and Harbour Basins. Madrid: Spanish National Ports \& Harbours Authority.

USACE. (2008). Coastal engineering manual, V(5). Navigation projects. Washington DC: Department of the Army, US Army Corps of Engineers.

Date of submission of the article to the Editor: 06/2018

Date of acceptance of the article by the Editor: 09/2018 